\title{
HER MAJESTY'S JUDGE
}

\section{Professor Philip S. James ${ }^{*}$}

With but one exception when our judiciary permit themselves to be greeted as "Her Majesty's Judges" political reality means that it is a pipe dream from the past. That one exception is Lord Denning (to whom our Law School owes so much) and the reason for it is that by awarding him the Order of Merit Her Majesty has marked him for Her Own.

It was many years ago that an insignificant person first caught a distant glimpse of the future judge. How peaceful now it seems; remembered so vividly. It was a summer's day, the sum was shining through the windows of a college library. As yet an undergraduate, this person was browsing there. Steeped, as he was in the myths and anomalies of legal history, he chanced to come upon a "case note" about a long forgotten case. Here was a contributor who had a contagious way of conveying his emotions to his reader and it was plain that he was angry. The object of his indignation was that he had smelt an injustice. It seemed that some judge or other had denied a claim based on unjust enrichment under the erroneous impression that the implied promise then considered necessary to support such a claim had to be a valid legal, rather than a fictional, one. Which had never really been the case. ${ }^{1}$ The unknown author of that note was a barrister called "A.T. Denning" and he had made a conquest.

If anybody ever had the magic of "charisma" it is Lord Denning. He seems in some strange way to dwell apart and, looking down on life, to see it "steadily and see it whole." by no means stands aloof: a friend of all the world if they will let him be he is easy of approach, likes to take people to himself and actually encourages them to call him "Tom."

Constrained to say a little of a lot let us now try to tell of him.

\footnotetext{
"Emeritus Professor, the University of Buckingham.

${ }^{1}$ Misunderstood by Lord Sumner in Sinclair v. Brougham [1914] A.C. 398. The fictional promise of indebitus assumpsit was invented in order to attract the King's Bench jurisdiction.

${ }^{2}$ Matthew Amold: Sonnet to A Friend.
} 
Here was a judge with an enviable ability to express himself lucidly, elegantly and simply. ${ }^{3} \mathrm{He}$ could convey the most complicated thoughts to the stupidest of people. But that was not all of it. His style of writing was not only literary but also to a high degree dramatic. It followed that he was able to pierce through the distorting mirror of the rules of evidence to paint a sensitive, lively, and sympathetic picture of the events of any case in which he was involved. Nobody forgets the pathos of the description of the railway disaster on the "bluebell line." And in quite another way in Lane v. Holloway he brought a colourful incident to life. "On July 1 st 1966," he began, "the peace of the ancient Borough of Dorchester was disturbed. The reason for that was that the plaintiff, after returning from a public house at 11.00 p.m., was talking to a friend in the yard off the High Street ..." As for what was to follow - the report of the case makes good reading.

In the second place it did not take long to discover that there were two Dennings. Since the recent furore of the Affaire Clinton it may by now have been forgotten that some years ago there was another affair which was incongruously staged in Cliveden the former stately home of conservatism. It was there that another uninhibited young lady called Christine Keeler became entangled with some political celebrities, thereby providing a bonanza for the Press. In the course of this titillating rumpus the Right Honourable Lord Denning, Master of the Rolls, was deputed to examine Miss Keeler in the course of his subsequent inquiry. Never was there a more ill-assorted pair. A day or so after His Lordship had interviewed Miss Keeler it happened that he had consented to speak at a students' dinner. When it came to speeches, with the solemnity to be expected of such a personage, the Master of the Rolls started by address his audience with the customary homily about professional behaviour considered appropriate upon such occasions. Then suddenly there came a characteristic twinkle in his eyes and the grave and learned personage gave way to the impish one. Out came the "Tom-boy" in him. Groping in his tailcoat pocket he dragged a copy of the Daily Mirror and brandishing it excitedly above his head, yelled, "Read this! The Mirror is telling us what it thinks about me and Christine Keeler!" which brought the house down. Years later we, of Buckingham, presented Lord Denning with the only gift we have to offer; our honorary degree. In the course of the ceremony the unwary fellow who was presenting him chose to compare him with Lord Mansfield to which, when it fell to him to reply, the newly fledged graduate retorted, "I hesitate to remind Professor X of

\footnotetext{
${ }^{3}$ His exposition of the Stevenage Case (Franklin v. Minister for Town \& Country Planning [1948] A.C. 87) in Freedom Under the Law (Stevens \& Co., 1949) at pp.120-121 is an excellent example of it.

${ }^{4}[1968] 1$ Q.B. 379.
} 
the story of the meticulous apothecary who put a notice in his shop window "WE DISPENSE WITH ACCURACY."

Turning from levity to the core and essence of Lord Denning's lifework, one does not know, though may suspect, that like many of his contemporaries the young Tom Denning would have been reared upon Sir Richard Burton's inspiring lines:

"Do as thy manhood bids thee / From none but self expect applause / He noblest lives and noblest dies / Who lives by none but self made laws."

That was Denning. Others might be content to hide their own discretion beneath a bramble bush of rules, but he despised such subterfuge. Like the all-powerful medieval Chancellors before him, guided only by the promptings of his conscience, he was fearlessly prepared to ride roughshod over, or else to circumvent, any rules of law which seemed to him to obstruct the path of Justice. By acting upon that principle he was to scandalise and alienate the Legal Establishment who seem actually to believe that it is possible to administer Justice "according to law." In support of this untenable proposition they insist that it is more important for the Law to be certain than it is for judges to be just. But nothing can be certain until it has occurred and no one can predict the outcome of a case until, the facts of it having been authoritatively ascertained, judgement has been passed upon them. When will the lawyers learn that we live in a continuum?

It took courage and conviction for one man alone to play the heretic but in his battle in the cause of justice Denning was to be unshakeable. In Central London Property Trust v. High Trees House Denning J. was to serve notice of his intentions. ${ }^{6}$ The plaintiffs in that case had gratuitously agreed to forgo rents due to them from the defendants in consequence of which concession the latter had extended a similar indulgence to tenants of their own. After a change of circumstance due to the ending of the War the plaintiffs were now having the effrontery to demand the repayment of those forgone rents. Incensed by the fact that the defendants had remitted their own tenants' debts in reliance upon the plaintiff's waiver of their own, Denning J.'s conscience told him that this was a flagrant breach of confidence which must not be countenanced at any price. But blocking the road to Justice, ahead of him lay the arcane and tangled rules of contractual "consideration." Not to be defeated, he skirted boldly around that obstacle by inventing what was to become known as promissory

\footnotetext{
${ }^{5}$ The famous nineteenth century traveller, explorer, linguist and scholar. Translator of the Arabian Nights.

${ }^{6}$ [1947] 1 K.B. 130.
} 
estoppel. This aroused a flutter in the dovecote. An upstart judge had used his own discretion to circumvent a settled Rule of Law!

The next landmark in this inexorable career is his inaugural Hamlyn Lecture, Freedom under the Law, ${ }^{7}$ in which the by-now Lord Justice Denning takes freedom for the centre for his theme. ${ }^{8}$ These four famous addresses are elegant, erudite and persuasive, but they do not tell all of the tale, and are sometimes economical with the truth. ${ }^{9}$ The reason for this is that the lecturer's mandate was to demonstrate the unique superiority of our common law. Thus he plays the advocate, puts all his wares in his shopwindow and unblushingly conceals the rest. For instance, wisely eschewing the Barons' charter (Magna Carta), he instances habeas corpus as the headstone of our freedoms but omits to remind his audience that that was designed rather to endow the monarchy with the monopoly of incarceration than to keep its subjects out of prison. When he extols the courageous part played by juries in the fight against oppression he mentions nothing of the fact that until the last vestiges of monarchical autocracy had gone, substantially with the sole exception of (F.W. Maitland's) "wonderful, masterful" Edward Coke, there was hardly a judge who ever dared to raise a finger in protection of the subject. The lecturer's professional eclecticism does credit to his powers of advocacy.

As for the after years - it would be tedious to recount how our Lord Denning was to become Master of the Rolls. It is hardly necessary to tell England of how his fame was to spread around the world. Go anywhere you please - his name will be familiar to almost any lawyer worth the name. So it continues. Only recently, the President and People of the French Republic have generously admitted him to the highest order of the Légion d'Honneur - an honour in the later years of his life in recognition of his youthful valour and participation in the Kaiser's War.

Throughout his spectacular career two characteristics in particular stand out in him: his love of justice and his loathing of autocracy. Many may remember how often from the bench he would complain about the welter of what a sixteenth century writer once deliciously described as the "stacks and shoals" of rules and regulations which were already pouring down upon our heads from the autocracy at Brussels. From the first to last it was Freedom that was his cry and, if memory serves right, his final speech before the Upper House of Parliament was devoted to waming our illustrious Emeritus Lady Chancellor of the menace that was lurking in the Single European Act. Another connexion - we for our part should not

\footnotetext{
${ }^{7}$ (Hamlyn Trust Series, Stevens \& Co., 1949).

${ }^{8}$ One senses the influence of Herbert Spencer and Dicey's masterly Law and Opinion in England in the Nineteenth Century (Macmillan \& Co., 1905).

${ }^{9}$ It was Miss Hamlyn's wish that the lecturers should tell the people of England about the superior virtues of the common law.
} 


\section{HER MAJESTY'S JUDGE}

forget how, like our former Chancellor (and Lord Chancellor) Lord Hailsham, unselfishly and magnanimously Lord Denning stooped to nurture the tender seedling of our infant University.

When, at length, weary of it, our Lord Denning turns away from the peepshow of this life it may be that there will be those who will say of him as it was said of the assassinated Lincoln, "Now he belongs to the Ages."

Tired of patching up the cracks and holes and woodrot in the crumbling fabric of our ancient legal system it may be that someone in the coming century will decide that the time has come to scrap it and replace it with a new one. Should that ever happen those entrusted with the task of making it might seek inspiration from the lifework of Lord Denning and if they should perhaps there might be two aspects of his judgements which would be particularly likely to interest them.

In the first place they might note that Denning preferred principles to rules and might conclude that that was because he realised that the field of application of a rule being less extensive than that of a principle from which it happens to be derived, a rigid application of a rule may easily result in denials of justice. It works like this. Assume there to be a principle that people who have in their control such dangerous things as tigers, large accumulations of water or high explosives ought to be held strictly responsible if, by escaping, they cause harm. Now assume, that a judge, having this principle in mind, by reference to the facts of the case before him, to formulate a rule ${ }^{10}$ to the effect that people who bring and keep upon their land anything likely to do damage if it "escapes" from that land are to be held strictly liable if it does escape and causes damage. Next suppose a case where a worker in a munitions factory injured by the accidental explosion of shell claims against her employers in reliance upon above the rule. A rule-bound court will see no option but to deny her claim upon the ground that because the plaintiff was on the factory premises at the time of the explosion there had been no "escape" of the explosive from the "land" in question. " Strange, indeed, and "lawyerly": one step into the road outside the factory gate would have made all the difference. A breach of the principle and a denial of justice.

Again there is a universal principle as old as history itself to the effect that it is culpably wrong to cause harm to others, either physical or in

\footnotetext{
${ }^{10}$ Rylands v. Fletcher [1861-73] All E.R. Rep.1.

${ }^{11}$ Read v. J. Lyons \& Co. Ltd. [1946] A.C. 156. One inveterate way of reconciling rules with principles is the trick - (seized upon as early as the ancient Roman priesthood) - of distorting the meaning of words: Midwood v. Mayor of Manchester [1905] 2 K.B. 597.
} 
respect of their fights to property. ${ }^{12}$ Based upon that principle the Theft Acts contain a complex set of rules intended to define it, but since to define is also to confine, the principle is inevitably wider than the rules. Since no one can forestall the infinity of circumstance which will amount to what the laity rightly consider to be "stealing" there is thus here a yawning moral gap between principle and rules which presents an open invitation to miscreants. This becomes self-evident when it is reflected that, as with the Larceny Acts before them, so it has been with the Theft Acts. Whenever a rogue takes advantage of the "gap" frenetic amendments have to be made to slam the stable door after the horse has bolted. Perhaps it might be a better remedy for such injustices if the principle were to be enacted into law and the courts left free to apply it at their discretion. It could be that that was how Lord Denning saw things. Justice cannot be guaranteed if it is administered "according to law."

The second thing that might attract the reformers' attentions is that, considered as a whole, one tends to get the impression from his judgements that Denning the judge is as sparing with his reasons as is Denning the advocate with the truth. If that impression is correct it may be worth asking why he should have been so sparing. May it be tentatively suggested that it might have been this. A wise old man once advised a younger one never to give a reason for anything he did because, he said, to do so is only to invite an argument. And that old man was right. That advice applies to a judge as well as anybody else. It can be argued paradoxically that once he condescends to give a reason for his decision, by opening the door to argument a judge can encourage litigation which is the very thing he is there to discourage.

Perhaps it might have been the scholar ${ }^{13}$ in the young Tom Denning that first inspired him by suggesting that it is neither reasons nor rules nor yet the ruling that follow them but only the million dollar question of what the judge will $d o^{14}$ about that ruling that really matters. And, subject to safeguards against gross abuse of power, to make such orders as may seem best to strike a fair balance between the interests of the parties to the case and (overridingly) between those interests and such interests as they

\footnotetext{
${ }^{12}$ At least as far back as Simonides $(556-469$ B.C.). The principle is the familiar one of the general duty of care propounded by Lord Atkin in Donoghue v. Stevenson [1932] A.C. 562. But it is fascinating to note that, sensing the danger that he had brought the idea of law too near (to the lawyer) to the realities of life, Lord Atkin hastily proceeded to turn his principle back into an unintelligible rule related specifically to the specific duties of manufacturers.

${ }_{13}^{13} \mathrm{He}$ did brilliantly at Oxford.

${ }^{14}$ Holmes' famous statement of a hundred years ago 'the predictions of what the courts will do in fact ... is what I mean by law"(1897) 10 Harvard Law Review 457) is not about justice in particular but reveals the truth that the facts in life are more important to us than our ideas. Devotees of Samuel Johnson will remember how he refuted Berkeley on this point.
} 
share with the public as a whole. Which, shom of its Olympian associations, is the pragmatic business of doing justice.

Much though we may dislike it, ${ }^{15}$ and as they may try to conceal it, we are ruled by other people not be laws.

By way of final salute to Denning (the reformer) it may be excusable to return to those reformers of the future. Their agendum would be a full one of very many items which cannot be unumerated here, but curiosity suggests that among them there might be expected to be some or all of the following. Whether in an advanced society it should be thought proper for the representative of authority to leave the formulation of the issues ${ }^{16}$ and the conduct of a trial to be fought out between the parties, only intervening in order to ensure that the rules of trial by battle are respected? Whether the time has come to do away with an incestuous sodality of Bench and Bar whereby promotion to the Bench is substantially restricted to members of the latter? ${ }^{17}$ Whether, being as different as is chalk from cheese, it is desirable that experience as an advocate should be considered the sole (or any) qualification for such promotion? Whether now that though even by legal standards tardily - it appears to be accepted that judges need some sort of training, it suffices that they should receive it both spasmodically and after, rather than before, appointment to the Bench?

What sacrilege is this? Everybody knows that our legal system is the envy of the world! Certainly in innate ability, legal expertise and integrity our judiciary are hardly to be bettered; but if they continue to rest content with the system that they operate there are some who never will be. Ask of the simpletons or of the incorrigible Peeping-Toms who look with horror and dismay at the sparseness of the Emperor's Clothes.

But come, having done our homespun best to sing the praises of this most famous man, now gaudientes, let us be ready to applaud him when, by a stroke of Time's bat, he reaches his memorable "century." Perhaps it might please him best if those of us who had the privilege of knowing him were to try to tell him what seemed to them the choicest of his many attributes. Was it his clear-sightedness? His originality? His indomitable quest of Justice? Was it, as it was once said of the greatest of our English

\footnotetext{
${ }^{15}$ Why do courts lean on precedents (or upon each other)? Why did the ruthless tyrant who sponsored the Code of Hammurabi attribute it to the superior authority of the Sun God?

${ }^{16}$ Long before the death of Caesar authority in the person of the Praetor supervised the formulation of the issues and why should a judge, who ought to represent the monarchy as parens patriae, not bear responsibility for the conduct of a case? Are we still haunted by the Spanish Inquisition?

${ }^{17}$ Tom himself might not have agreed with this. He used to say that the close association of Bench and Bar enabled the former to monitor the latter. He forgot that the common tradition was for the judges to have a separate inn. Moreover, the increase in numbers now erodes his thesis.
} 


\section{DENNING LAW JOURNAL}

judges, the "jewel of his mind?" Was it his powers of exposition? Was it that literary ability of his of which he was so justly proud? Was it his wit and charm? His courtesy? His moral courage?...

It could be that it was none of those things. It could be that it was his magnanimous humility, his sense of the pettiness and transience of life, that led him to behave towards the meanest of us as though we were on equal terms with him. Perhaps, it might have been? And perhaps, after all, in this he was right. Perhaps he really is just like all of ... Perhaps ... perhaps he is ... but ...

.... He is greater. ${ }^{18}$

${ }^{18}$ Acknowledgements to Samuel Johnson's fickle Hester Thrale. 